\title{
What Happens with the New Guy? Tackling the Problem of Tacit Knowledge through Social Networks
}

\author{
Alexandra Galli-Debicella (Corresponding author) \\ Ancell School of Business, Western Connecticut State University \\ 181 White Street, Danbury, CT 06810, United States \\ Tel: 1-203-837-8181Ｅ-mail: gallidebicellaA@wcsu.edu
}

Received: August 6, 2020 Accepted: Sep. 26, $2020 \quad$ Published: October 1, 2020

doi:10.5296/jmr.v12i4.17696 URL: https://doi.org/10.5296/jmr.v12i4.17696

\begin{abstract}
Tacit knowledge is the key to business continuity and retaining core knowledge during organizational change. Corporations have recognized its importance and implemented knowledge management strategies to ensure valuable knowledge is preserved. While much of the academic research has looked into the nature of tacit knowledge, the role of social networks in maintaining tacit knowledge has been largely unexplored. The following paper seeks to link existing tacit knowledge theory with social network theory through theoretical analysis and literature review. First, social networks are more important when tacit knowledge cannot be codified and when the nature of that knowledge is process-based. Second, while the strength of relationships tends to increase the effectiveness of tacit knowledge transfer, weaker relationships tend to dominate the actual transfer of knowledge. Third, asymmetry in relationships tends to decrease effectiveness of tacit knowledge transfer. The purpose of the paper is to explore when social networks matter more for tacit knowledge communications and what types of social networks are most effective at transmitting tacit knowledge.
\end{abstract}

Keywords: Tacit knowledge, knowledge, knowledge transfer, social networks, information 


\section{Introduction: An Unexplored Intersection}

Transmitting tacit knowledge from experienced workers to new workers is widely recognized as difficult and challenging for organizations (Haldin-Herrgard, 2000; Hau, Kim, \& Lee, 2016). The formal and informal social networks that constitute an organization play a large role in how effective tacit knowledge is communicated among employees. Tacit knowledge is information and patterns contained in the minds of experienced workers, which is difficult to communicate to newer workers because of its specific and complex nature (Nonaka, 1994; Polanyi, 1966). During the course of a career, employees build up knowledge of process and content in relation to their roles that are not codified anywhere within the firm. It is resident in their heads, and they do not have to communicate it on a regular basis (even though they may use it every day). When it is time to pass on knowledge to newer workers, tacit knowledge poses a problem for firms unless an effective communication mechanism is established. The literature has discussed how tacit knowledge is difficult to both communicate to others and directly teach others due to its highly personalized nature (Ambrosini \& Bowman, 2001; Li-Wei \& Lin, 2013; Nonaka, 1994; Reed \& Defillippi, 1990; Simonin, 1999; Swap, Leonard, Shields, \& Abrams, 2001; Wipawayangkool \& Teng, 2016). While much as been written in academic literature about the problems related to communicating tacit knowledge, more attention is needed surrounding the role of social networks.

Social network theory deals with the structure, strength, and symmetry of relationships within an organization (Brass \& Burkhardt, 1993; Brass, Butterfield, \& Skaggs, 1998; Mead, 2001). Outside of the "formal" reporting structure, employees have complex social relationships in their daily interactions. Social networks have a number of variables that can affect the relationship between experienced and newer workers. For example, two important variables are symmetry (if one person is more powerful than the other) and strength (the emotional closeness of the relationship). These interactions can have huge impacts on how tacit knowledge is shared between those employees.

This paper attempts to address a gap in the literature by examining the intersection of tacit knowledge transfer and social networks. The paper offers several propositions to investigate the complex interaction of the types of communication (in regards to tacit knowledge) and the types of social networks. Many combinations are possible, but certain arrangements will result in more effective transmission of tacit knowledge within a social network. The paper explores the inherent problems tacit knowledge creates for organizations and the communication methods typically utilized to transmit tacit knowledge to new generations of workers. The paper also discusses the theory of social networks to define the variables (structure, strength, and symmetry) that outline different types of relationships.

\section{Tacit Knowledge}

The literature has long recognized knowledge as a source of competitive advantage for organizations (Grant, 1996b; 1997). Knowledge is the understanding through individual learning and perception (Grant, 1996b; Polanyi, 1966). Knowledge can be a significant organizational resource if it comprises characteristics that are valuable, rare, inimitable and 
non-substitutable characteristics, even more so if it has a tacit dimension (Polanyi, 1966; Seidler-de Alwis \& Hartmann, 2008).

There are two distinct types of knowledge: tacit knowledge and explicit knowledge (Grant, 1997; Polanyi, 1966). Michael Polanyi defines tacit knowledge as the understanding that is developed through observations and practice that cannot be clearly codified and communicated. Everyone provides their own distinct meaning, based on their collection of tacit knowledge, when articulating knowledge (Polanyi, 1966). Tacit knowledge is usually unstructured and incorporates experience-based features (Borges, Bernardi, \& Petrin, 2019). Thus, tacit knowledge is inherently build up in a persons' mind and is difficult (though not impossible) to codify. Another view is from Martin Davies, who utilizes a linguistic approach to define tacit knowledge as a "certain kind of causal-explanatory structure which underlies, or is antecedent to, the pieces of knowledge that the speaker has concerning complete sentences" (1989: 542). Davies sees tacit knowledge as a way to explain structure without the need to be explicitly stated.

Tacit knowledge is not written down anywhere - although there is some disagreement as to whether it could be. Most academics believe that tacit knowledge can never be written down and that tacit knowledge ceases to be tacit if it can be written down. Tacit knowledge is the "knowing how" instead of "knowing about" where it can only be shown through application and practice, which is not possible through codification (Grant, 1996a; 1996b; Kogut \& Zander, 1992). Moreover, codifying tacit knowledge may redirect the focus to the particulars instead of the entity. As a result, the focus change may cause people to lose sight of the entity and the related tacit knowledge all together (Polanyi, 1966). However, it is worth noting that some authors believe that tacit knowledge can be written down, but is not because of the sheer volume of knowledge (Selamat \& Choudrie, 2004). While tacit knowledge ceases to be tacit when it is written down, it remains tacit if it could be written down but remains unwritten. This more accurately reflects the reality of most corporations today, so the more permissive definition of tacit knowledge as knowledge not currently written down is stronger.

However, once knowledge is written down (or otherwise codified), it is generally accepted to be explicit knowledge (Grant, 1996b; Selamat \& Choudrie, 2004). Explicit knowledge is knowledge that can be both communicated and shared through language and writings (e.g., through manuals and texts). Explicit knowledge is referred to sometimes as "knowing about" or "knowing what" (Brown \& Duguid, 1998; Grant, 1996a; 1996b; Kogut \& Zander, 1992) as it is centered on objective and rational knowledge (Wellman 2009). Moreover, explicit knowledge is knowledge that can be standardized and reproduced easily for other people since it can be easily identified, stored and retrieved (Liao, 2005; Polanyi, 1967; Wellman, 2009).

\subsection{Opportunities and Challenges of Tacit Knowledge}

Tacit knowledge presents interesting opportunities and challenges for organizations. Tacit knowledge can provide a real competitive advantage for firms because it is hard to replicate by its very nature (Berman, Down, \& Hill, 2002; Chen, Miguel, Ragsdell, \& An, 2019; Grant, 1996b; Hau, Kim, \& Lee, 2016; Huang, Wang, \& Yao, 2019; Li-Wei \& Lin, 2013; Lubit, 
2001; Wipawayangkool \& Teng, 2016). Knowledge that is in employees' brains is difficult to replicate in other firms because it is based on a unique set of experiences (Bhatt, 2001; Grant, 1996b; Haldin-Herrgard, 2000; Reed \& Defillippi, 1990). Tacit knowledge around process often comes together to form a strong foundation of culture (Ghoshal \& Bartlett, 2000; Hurley, 2002; Lawler, 2004). Examples such as McKinsey \& Company, which is known to have a culture of excellence in management consulting, is based on inherent knowledge of the "McKinsey Way" to operate businesses - much of which is not codified, but is built into the "DNA" of McKinsey consultants. The literature has also found that when greater tacit knowledge is generated within the firm, employees are better able to develop novel products as well as improve existing products (Palacios-Marqués, Popa, \& Alguacil Mari, 2016). It is inherently difficult for competitors to replicate tacit knowledge, therefore organizations that utilize their employees' tacit knowledge for innovational pursuits can gain an advantage (Panahi, Watson, \& Partridge, 2013).

However, tacit knowledge also presents an inherent problem-how to replicate such knowledge to new employees. Gertler (2003) illuminates the properties of tacit knowledge by discussing its three inherit and perpetual issues. The first issue is how tacit knowledge is produced. It is difficult for firms and its managers to understand how tacit knowledge is created and how to make investments that will facilitate its creation. The second issue is how can firms find tacit knowledge from their individual employees and correctly utilize it for the bettering of the firm. The third issue is how can firms reproduce tacit knowledge and share it among internal employees (Gertler, 2003). The aforementioned problems with tacit knowledge come down to the single point that it cannot be easily conveyed, as its owner never had to state the knowledge in a clear and precise way (e.g. subjective insights, intuitions, and hunches). Moreover, the transfer of tacit knowledge is sensitive to both social and situational context, which can be difficult to replicate for educational purposes. Unlike explicit knowledge, tacit knowledge has to be internalized by the individual within a social context in order to be appropriately understood. Lastly, tacit knowledge also experiences issues of being rapidly outdated in an increasingly changing world of practice (Chen, et al, 2019). Thus, the methods of communication of tacit knowledge become of paramount importance for organizations seeking to use tacit knowledge to build competitive advantage.

\subsection{Communicating Tacit Knowledge}

Many studies have analyzed the effectiveness of "systems" (information technology or knowledge management systems) in capturing tacit knowledge (Desouza, 2003; Malhotra, 2002; Nonaka, 1994; Selamat \& Choudrie, 2004; Wipawayangkool \& Teng, 2016). Many find that "one-size-fits-all" solutions are not effective at capturing and communicating tacit knowledge - that a more nuanced view is necessary in order to better determine how to best transfer tacit knowledge.

Many firms implement learning management systems (like software) to capture and distribute tacit knowledge, however they fall short by coming across as "a one size fits all" solution (Desouza, 2003). Knowledge management systems can be unsuccessful due to their inherent design, which unravels and becomes a constraint in adapting and changing to an environment 
that is considered dynamic and uncertain. These failures are the results of gaps between within the value the firms create and the value demanded by market conditions. As a result, the task of tacit knowledge capture gets pushed aside in order to resolve the inefficiencies of the firms' knowledge management systems (Malhotra, 2002; Selamat \& Choudrie, 2004).

Moreover, organizations are unsure that the benefits of capturing tacit knowledge will sufficiently justify the costs. Selamat and Choudrie (2004) argue how individuals can externalize and document their tacit knowledge in order for firms to use that knowledge as a basis to maintain information systems up to date with pertinent best practices. However, the costs for firms to document each individuals' knowledge can be too expensive and time consuming for firms to actually pursue. Additionally, the transfer between individuals is often slow and uncertain (Grant, 1996b; Kogut \& Zander, 1992). Organizations, particularly those in fast paced and dynamic environments, may not have the time or budget to pursue such programs. Thus, the importance of informal relationships and the importance of social networks regarding tacit knowledge becomes amplified. By understanding these issues, firms will be in a better position to justify the need of capturing tacit knowledge and determining the method to capture and distribute that knowledge throughout the firm.

\section{Communicating Tacit Knowledge}

The intersection of tacit knowledge and social networks is how knowledge is communicated between individuals within a network. Communication between employees of a firm enables knowledge that is in one employee's head to be transmitted to another. This is important when a new employee joins the firm. Moreover, the effectiveness of such communication is essential to an organization's success when older employees leave the firm, as their tacit knowledge will also leave unless communicated. Therefore, the question of what variables lead to different communication approaches for tacit knowledge arises. In order to understand the link between tacit knowledge and social networks, it becomes important to look at the attributes that indicate the communication methods would be most effective in specific types of social networks.

\subsection{Predictive Attributes}

The attributes that help match communication method with social network are the nature of the tacit knowledge (content versus process) and the codification of knowledge (can be codified or cannot be codified). The nature of tacit knowledge involves whether the knowledge is related to job content (e.g., technical details of a product, information about customer accounts) or the process of working within the particular firm (e.g., how to get a sales discount approved for a customer, the realities of annual budgeting). Academic literature in knowledge management has discussed how the focus on the process is commonly seen as the "how" while the focus on the content is referred to as the "what" (Byosiere, \& Luethge, 2008; Davenport \& Prusak, 1998; Nahapiet \& Ghoshal, 1998). The codification of knowledge is related to whether the information could ever be written down (e.g., creating a process chart for annual budgeting) or could only be communicated orally or through observation (e.g., what informal social interactions work best with certain clients). As a result, social networks will be more or less effective in transmitting tacit knowledge depending on 
which method of communications is appropriate in a given situation. Taken together, these two attributes form a matrix of how tacit knowledge can be communicated among employees in an organization.

The academic literature has also extensively discussed common forms of communication in an organization (mentoring, training, organizational learning, and manuals). This paper argues that the different forms of communication fit better at different points in the matrix. In the remainder of this section, the communication forms are explored and a matrix of common communication methods of tacit knowledge is offered.

Mentoring can be a formal or informal communication method, where content-based tacit knowledge is shared in a one-on-one setting. Mentoring is done around a specific role or position in a firm (e.g., financial analyst), not just between any employees. Thus, the knowledge transmitted tends to be content-based and specific to the knowledge built up by an employee in a particular role over many years. Furthermore, knowledge communicated by mentoring usually cannot be codified, because if it could, mentoring would be an inefficient way of communicating it relative to alternatives. (Higgins \& Kram, 2001).

While mentoring is one-on-one, training is typically pursued as one-on-many. Training involving tacit knowledge is defined as taking content-based knowledge that can be codified and communicate on a one-to-many basis. The main difference between mentoring and training is that the knowledge can be structured and codified. For example, knowledge of how to select what analysis might be appropriate for a given situation has a few guidelines, but no hard-and-fast rules; such tacit knowledge is more appropriate for mentoring. By contrast, showing employees how to do different types of analysis is knowledge that can be communicated on a repetitive basis in a structured manner (that could be written down if necessary), thus tacit knowledge amenable to training (Liau, 2005).

Organizational learning is firm-specific knowledge of process that is contained in the "DNA" of an organization. Such knowledge is usually not apparent to "outsiders" (typically those outside the organization), as how things are done at an organization tends to be more tacit than any other type of knowledge (e.g., how to get a purchase order approved, the internal politics of the budgeting process). Unlike mentorship, organizational learning almost always takes place in informal settings and outside the official sanction of the firm (Liu, 2005). Because such knowledge can only be built through experience at the firm, communication also tends to be "action-oriented" rather than merely talking. Newer employees learn by walking through the process with experienced workers.

Lastly, manuals are the ultimate in codifying tacit knowledge-indeed, once the tacit knowledge is created into manual form it is no longer tacit (Bryant, 2005; Grant, 1996; Kogut \& Zander, 1992; Nahapiet \& Ghoshal, 1998). Manuals enable the capture of tacit knowledge around processes and content, which can be easily communicated to others without the presence of a "teacher". Tacit knowledge amenable to this codification is either process-related (e.g., writing down the process map of the budgeting process) or basic, entry-level content. 


\section{MInstitute ${ }_{\text {Int }}^{\text {Macrothink }}$}

Journal of Management Research

ISSN 1941-899X

2020, Vol. 12, No. 4

Taken together, this paper offers a matrix of common communication methods of tacit knowledge.

Table 1. Methods of Communicating Tacit Knowledge

\begin{tabular}{|c|c|c|c|}
\hline & & \multicolumn{2}{|c|}{ Can it be codified? } \\
\hline & & No & Yes \\
\hline \multirow{2}{*}{$\begin{array}{l}\text { Nature of } \\
\text { knowledge }\end{array}$} & $\begin{array}{l}\text { Content } \\
\text { (role-specific } \\
\text { knowledge) }\end{array}$ & Mentoring & $\begin{array}{l}\text { Training and Education } \\
\text { (e.g. real-time or } \\
\text { classroom) }\end{array}$ \\
\hline & $\begin{array}{l}\text { Process } \\
\text { (how things } \\
\text { are done) }\end{array}$ & $\begin{array}{c}\text { Organizational } \\
\text { learning } \\
\text { (e.g. informal passing } \\
\text { on of insights) }\end{array}$ & Manuals \\
\hline
\end{tabular}

\section{Social Networks}

Social networks can be defined as "a specific set of linkages among a defined set of persons, with the additional property that the characteristics of these linkages as a whole may be used to interpret the social behavior of the persons involved" (Mitchell, 1969: 2). Essentially, the focus is centered on the relationships between the actors and the effects those relationships have. In communicating tacit knowledge, the nature of the relationship will have a significant impact in how effectively the tacit knowledge is shared. The academic literature has extensively explored the relationships in social networks including the dimensions of strength and symmetry (Brass \& Burkhardt, 1993; Brass, Butterfield, \& Skaggs, 1998; Mead, 2001).

According to Granovetter, the strength of a tie is a "combination of the amount of time, the emotional intensity, the intimacy (mutual confiding), and the reciprocal services which characterize the tie" (Granovetter, 1973: 1361; Granovetter, 1983). Strong relationships are those close circles of friends and work associates with a certain minimum of interaction and trust. Weak relationships are casual acquaintances with no need for deep trust. Two key questions arise around tacit knowledge and relationship strength: First, are strong relationships necessarily better at transmitting tacit knowledge? Second, is tacit knowledge typically transmitted through stronger or weaker relationships? Ties that are weak often involve common, everyday contact that might be conducive to communicating certain types of tacit knowledge.

Symmetry refers to degree to which trust is balanced in a relationship. Asymmetric relationships are when the "trust and emotional involvement of one actor are not reciprocated by the other" (Brass \& Burkhardt, 1993; Brass, et al, 1998: 19; Carley \& Krackhandt, 1990). While symmetric relationships tend to result in stronger relationships in the long term, asymmetric relationships often result in skewed incentives for the parties involved in the 
relationship. In tacit knowledge transfer, an asymmetric relationship may result in either too much or too little knowledge being transferred. For example, the experienced employee may not want to transmit knowledge if they perceive that the newer employee could supplant them in their job. Therefore, asymmetrical relationships could reduce the effectiveness of tacit knowledge communication.

\section{Tacit Knowledge and Social Networks}

It becomes important to understand whether dimensions of social networks interact with the types of communication methods in regards to tacit knowledge. Especially considering three out of the four communication methods (mentoring, training, and organizational learning) involve social interactions between an experienced employee and a newer employee. Both strength and symmetry of relationships are likely to have major effects on the effectiveness of these communication methods. Thus, interactive effects of multiple permutations of communication methods and social network dimensions are further explored in order to understand how tacit knowledge is best shared.

To structure these permutations, two fundamental inquiries are considered: in which communication methods do social networks matter more and how do relationship strength and symmetry affect the effectiveness of the various communication methods? When considering the first of these two questions, the two dimensions that formulate the tacit knowledge communication matrix need greater examination. The nature of the knowledge (process versus content) and whether the knowledge could be codified (can or cannot be codified) are the two axes on which to consider where social networks matter.

The first dimension in the communication matrix is whether knowledge can be codified. Note that the knowledge is not actually codified (in which case it would no longer be tacit), but rather has to do with potential to be codified. Social networks are likely to matter more when knowledge cannot be codified, as the only way they can be communicated is orally (Droege \& Hoobler, 2003). As a result, social interaction is inherently necessary for organizations when their knowledge cannot be codified and easily retrieved by employees.

Social networks will thus play a greater role in mentoring or organizational learning communication, and a lesser role in training or manuals. The effectiveness of mentoring will heavily influence the strength of the relationship, where a trusting relationship could significantly increase the "teacher's" willingness to pass information onto the "student" (Liau, 2005). Organizational learning, with its more informal nature, is likely even more dependent on a strong, trusting relationship to relay information on idiosyncratic people and processes within the firm (Liu, 2005). Similarly, both mentoring and organizational learning could be less effective through asymmetrical relationships, where one person has an incentive to not share valuable information.

By contrast, both training and manuals will likely be less impacted by social networks. Manuals are inherently not affected by social networks, since writing and reading a manual are usually each solitary pursuits. Training and education are social processes but are often one-on-many rather than one-on-one. Social networks may play a role in training, but in very 
subtle and indirect ways. For example, a teacher may favor students with whom they have strong relationships, or the complex structure of relationships may lead to skewed incentives for teacher or student. However, the fact that training is inherently structured and public (relative to mentoring or organizational learning) creates both peer pressure and monitoring effects that reduce the impact of social network on the efficacy of tacit knowledge communication. Thus, the paper proposes:

Proposition 1: Social networks will positively influence the effectiveness of tacit knowledge transfer when that knowledge cannot be codified.

The second dimension is whether the knowledge is process or content based. Focusing on knowledge that cannot be codified (and thus Proposition 1 is more likely to be influenced by social networks), the question is whether mentoring (content-based) or organizational learning (process-based) will be more influenced by social networks. Both are one-on-one social interactions, but mentoring can be more formalized and is typically more structured (Higgins \& Kram, 2001). Organizational learning around firm-specific process tends to be more informal because the tacit knowledge tends to be more sensitive-knowledge about specific people or the "unofficial" way to do things (Bouty, 2000; Droege \& Hoobler, 2003). The reason that organizational learning tends to be more informal therefore increases the importance of social networks.

Informality of knowledge transfer increases the role of social networks because factors other than the tacit knowledge increase in significance. More formal mentoring typically involves content-based knowledge that is compelling outside the social context of the organization (for example the intricacies of programming code or how to make a compelling automotive parts sales call) (Higgins \& Kram, 2001). Such tacit knowledge is what usually is outside the social context of the organization. On the other hand, informal organizational learning is inherently about processes that are specific to the context of the firm (for example how to build a coalition to get a proposal approved by the CEO). Because this informal knowledge transfer is more context-specific, social network factors such as the strength of the relationship or asymmetry in the relationship will have a greater impact on the transfer of knowledge (Bouty, 2000; Droege \& Hoobler, 2003).

However, the opposite appears to occur when considering knowledge that can be codified. Social networks inherently have a greater role in training and education, than in manuals, because of the solitary nature of writing and reading manuals. Thus, if limited to non-codifiable knowledge, social networks influence process tacit knowledge transfer more than content tacit knowledge. Therefore, this paper proposes that social networks will influence the success of tacit knowledge transfer more when that knowledge is related to process, rather than content:

Proposition 2: Social networks will positively influence the effectiveness of process related tacit knowledge transfer.

The second area of propositions is around the two social network dimensions that influence tacit knowledge transfer. Specifically, the paper investigates the role of relationship strength 
and relationship symmetry. The succeeding section will discuss relationship strength and knowledge transfer, followed by a section about relationship symmetry and knowledge transfer.

Granovetter classifies social ties into strong or weak in terms of tie strength, which is defined as "a combination of the amount of time, the degree of emotional intensity, the level of intimacy, and the degree of reciprocity between two individuals" (1973, p. 1361). Strong ties are relationships among close-knit members who engage in frequent interactions. These types of relationships are commonly between close friends and family. Whereas weak ties are relationships among socially distant members who engage in infrequent interactions. These types of relationships are common between strangers and acquaintances (Granovetter, 1973).

Strong-tie relationships might be expected to be more effective than weak-tie relationships in transmitting tacit knowledge. Relationships with strong-ties are usually those found in close physical and psychological proximity to each other, which helps promote information seeking and sharing (Hu, Wang, Jiang, \& Yang, 2019; Reingen \& Kernan, 1986). Moreover, strong-tie relationships develops a solid base of member familiarity based on those members' needs and preferences. This in turn encourages those members to share valuable and relevant information (Chung \& Tsai, 2009). Therefore, close emotional ties and trust-based relationships might be more amenable to sharing tacit knowledge openly and fluidly. For example, in strong relationships, new employees will be more willing to ask questions and tenured employees will be more willing to correct errors to ensure the knowledge is transferred properly. In weaker relationships, knowledge might not be shared to same extant (e.g. as in depth) with the newer employee because of a lack of trust-especially so if that knowledge is difficult to communicate, complex, or politically sensitive.

However, tacit knowledge is actually more likely to be spread through weak relationships (Droege \& Hoobler, 2003; Granovetter, 1973). Weak-tie relationships typically exist between members who do not have much in common, including other contacts and information. This allows information to be shared widely and rapidly among its members. This is in contrast to strong-tie relationships, where information tends to be redundant as those members share similar interests, friends, contacts and information. Consequently, information becomes harder to share outside strong-tie relationships. Therefore, weak-tie relationships create bridges to a much wider network for its members (Granovetter, 1973).

Weak ties also support the spread of information from one group to another (Brown \& Reingen, 1987). Granovetter (1973) argues that weak ties play an important role in the flow of information through a study of job mobility. In his pioneering labor market study, Granovetter shows how individuals are able to locate prospective job opportunities more often through ties that are weak than those that are strong (Granovetter, 1973). Specifically, information relating to job employment was more likely to come from one's acquaintances than from one's close friends. This understanding is reinforced by the marketing literature, as a commonly accepted view is that weak ties have a greater impact on the market-level spread, while strong ties have a greater impact on interpersonal influence (Brown \& Reingen, 1987; Frenzen \& Nakamoto, 1993; Godes \& Mayzlin, 2009; Hu, et al, 2019). 


\section{Mll Macrothink}

Journal of Management Research

ISSN 1941-899X

2020, Vol. 12, No. 4

The majority of relationships at an organization are weak, since employees have greater informal contacts they work with during the day than close, trusting relationships. Tacit knowledge takes many forms and that knowledge is frequently transferred informally between dissimilar individuals with weaker relationships to each other (e.g. engineer from one firm talking to a computer programmer in another firm). The sheer number of weak ties and everyday interactions involving communication of tacit knowledge makes it the more common transmission. Therefore, this paper proposes that tacit knowledge is shared and spread significantly more through weak relationships than strong relationships, even though strong relationships (usually taking the form of strong, mentoring relationships) tend to be more effective in ensuring that the maximum amount of knowledge is actually transferred:

Proposition 3: Tacit knowledge will be positively shared more through weak relationships, though strong relationships may be more effective.

The concept of symmetry in relationships is to determine whether hierarchy is or is not present in a relationship (Linell \& Luckmann, 1991). Symmetry refers to the degree that trust is considered balanced between members in a relationship. When trust is high in a relationship, both uncertainty and opportunism decreases while commitment to relationships increases (Wu, 2011). Researchers have found that trust is effective in facilitating tacit knowledge sharing (Huang, Davison, \& Gu, 2011; Rutten, Blaas-Franken, \& Martin, 2016). Specifically, that affect-based trust increases the willingness to share tacit knowledge among co-workers, while cognition-based trust has increases the willingness of co-workers to use tacit knowledge (Holste \& Fields, 2010). Therefore, symmetric relationships are those that result in the equal sharing of information. Members in symmetric relationships tend to experience stronger relationships in the long term as trust is reciprocated.

Conversely, knowledge asymmetry is a situation in which one party is better informed about some aspects of the exchange relationship than is the other party (Bergen, Dutta, \& Walker, 1992; Dou, Li, Zhou, \& Su, 2010). Asymmetric relationships are when the trust and emotional involvement of one party is not reciprocated by the other party. Simply stated, there is an inequality among the actors involved in the relationship. Imbalance in relationship could become a detrimental barrier to cooperation. In these scenarios, relationships are often dominated by formal agreements, instead of trust (Michalski, Montes, \& Narasimhan, 2019). While this may ensure access to things like resources, it does not encourage innovative cooperation (Colurcio \& Russo-Spena, 2013, Michalski, et al, 2019). In one study, researchers found that more than $70 \%$ of employees hide their knowledge from their fellow colleagues (Connelly, Zweig, Webster, \& Trougakos, 2012). Moreover, studies have explored the negative influence of asymmetry on relationship stability, dissatisfaction and network development or performance (Johnsen \& Ford, 2008; Thomas \& Skinner, 2010). As a result, there is an inequality among the employees involved that can negatively impact those actors as trust is not reciprocal.

Asymmetry in relationships tend to create barriers to effective communication of tacit knowledge because of skewed incentives of the parties involved. If one party trusts the other, but that trust is not reciprocated, there will be incentives to aggressively take knowledge or 
hold it back-either way reducing the effectiveness of knowledge transfer. For example, tenured employees who believe that the new employee is trying to take advantage of their tacit knowledge will likely not communicate everything they know. Moreover, new employees who aggressively pressure the tenured employees for knowledge are likely to create awkwardness that disrupts the normal flow of information. Therefore, this paper proposes that symmetrical relationships tend to be more effective at transmitting tacit knowledge than asymmetrical relationships:

\section{Proposition 4: Symmetrical relationships will positively transmit tacit knowledge.}

\section{Discussion}

Knowledge is key when it comes to a firm's competitive advantage and is a driver for the firm's value as well (Grant, 1996b). The firm can maintain, if not expand, their competitive advantage when employees are encouraged to share their valuable knowledge to others in their organization (Grant, 1996; Liu \& Phillips, 2011). Knowledge sharing within the organizational workforce can be a crucial determinant in attracting more customers, increasing product and service sales, and retaining a highly qualified workforce (Huang, et al, 2019). As a result, it becomes important for firms to prioritize knowledge sharing among their employees. Specifically, tacit knowledge that is difficult for employees to be conscious of or to express in language, but employees draw on as they are using that knowledge (Hadjimichael \& Tsoukas, 2019). Much of the academic research has looked into the nature of tacit knowledge. Given its inherent complexity, social networks and tacit knowledge are a largely unexplored arena that deserves more attention. This paper tried to address this deficiency by specifically looking at when social networks matter more for tacit knowledge communications and what types of social networks are better at transmitting tacit knowledge.

While intangible ideas like social networks and tacit knowledge are difficult to quantify, this paper attempts to shed light on when social networks might matter more for tacit knowledge communications and what types of social networks are most effective at transmitting tacit knowledge. Through the propositions, this paper provides several important implications. First, social networks become more important for firms to consider when tacit knowledge cannot be codified and when the nature of that knowledge is process-based. Second, while the strength of relationships between employees tends to increase the effectiveness of tacit knowledge transfer, weaker relationships tend to dominate the actual transfer of knowledge. Third, relationship asymmetry will likely decrease the effectiveness of tacit knowledge transfer. Moreover, the "Methods of Communicating Tacit Knowledge" matrix demonstrates that the two attributes of "nature of the tacit knowledge" (content vs. process) and "codification of knowledge" (can be codified or cannot be codified) are important when it comes to communication methods for tacit knowledge. The matrix offers a fresh perspective for organizations to determine the proper communication method for tacit knowledge.

The purpose of this paper is to not only present these propositions in regards to the theory and academic literature, but also eventually test them for future research. The subsequent step is to test these propositions as part of an overall research agenda on tacit knowledge. By transforming the propositions suggested in this paper into testable hypotheses, the hope is to 
initiate a discussion that will contribute to the existing base of knowledge about tacit knowledge and social networks. The limitations in this paper offer rich opportunities for further research.

First, this paper identified the attributes around tacit knowledge (nature of knowledge and whether it can be codified) that were especially critical, but there other attributes that could be considered. Complexity of knowledge and specificity of knowledge could also affect the effectiveness of varying communication methods. At the same time, social networks have many characteristics beyond strength and symmetry, which could affect tacit knowledge. For example, the complexity of relationship structure (e.g., peer pressure, monitoring, and interdependent relationships) likely has an impact on how effective tacit knowledge transfer is. Therefore, additional research should explore other attributes when dealing with tacit knowledge in organizations.

Second, the communication methods of tacit knowledge are likely to have interactive effects with other factors besides social networks. Specifically, small and medium sized firms are likely to communicate tacit knowledge in a different manner than in resource-rich large firms. In addition, different industries could have different emphasis in communication methods that should be further explored. Therefore, it would be of great interest to investigate the differences in communication based on firm size as well as industry type. Although this study is not free from limitation, the hope is that the limitations of this study will direct future inquiry as well.

Conceptual papers can "bridge existing theories in interesting ways, link work across disciplines, provide multi-level insights, and broaden the scope of our thinking" (Gilson \& Goldberg, 2015, p. 128). Specifically, the propositions presented here may have practical managerial implications with how firms operate but also how they manage tacit knowledge with existing and new employees. Therefore, an ongoing discussion could benefit tacit knowledge sharing, as well as the overall success of the organization. It also suggests that the next phase is to test these propositions for future research through extensive data collection and rigorous analysis, as there is still much to learn about tacit knowledge and social networks.

In conclusion, this paper aims to stimulate the conversation around tacit knowledge and social networks in firms. The propositions proposed in the paper contribute to the overall investigation of tacit knowledge and suggest opportunities for future research. Ultimately, more attention is needed to understand how important social networks are on tacit knowledge sharing within an organizational context. Through greater understanding, firms can improve their effectiveness in managing the communication of tacit knowledge, which in turn can lead to better information sharing among employees of the firm.

\section{References}

Ambrosini, V. \& Bowman, C. (2001). Tacit knowledge: some suggestions for operationalization. Journal of Management Studies, 38(6), 811-829. https://doi.org/10.1111/1467-6486.00260 


\section{Macrothink}

Journal of Management Research

ISSN 1941-899X

2020, Vol. 12, No. 4

Bergen, M., Dutta, S., \& Walker Jr., O. (1992). Agency relationships in marketing: A review of the implications and applications of agency and related theories. Journal of Marketing, 56(3), 1-24. https://doi.org/10.1177/002224299205600301

Berman, S., Down, J. \& Hill, C. (2002). Tacit knowledge as a source of competitive advantage in the National Basketball Association. Academy of Management Journal, 45(1), 13-31. https://doi.org/10.2307/3069282

Bhatt, G. (2001). Knowledge management in organizations: Examining the interaction between technologies, techniques, and people. Journal of Knowledge Management, 5, 68-75. https://doi.org/10.1108/13673270110384419

Borges, R., Bernardi, M., \& Petrin, R. (2019). Cross-country findings on tacit knowledge sharing: Evidence from the Brazilian and Indonesian IT workers. Journal of Knowledge Management, 23(4), 742-762. https://doi.org/10.1108/JKM-04-2018-0234

Bouty, I. (2000). Interpersonal and interactional influences on informal resource exchange between R\&D researchers across organizational boundaries. Academy of Management Journal, 43(1), 50-59. https://doi.org/10.2307/1556385

Brass, D. \& Burkhardt, M. (1993). Potential power and power use: An investigation of structure and behavior. Academy of Management Journal, 36(3), 441-470. https://doi.org/10.2307/256588

Brass, D., Butterfield, K., \& Skaggs, B. (1998). Relationships and unethical behavior: A social network perspective. Academy of Management Review, 23, 14-31. https://doi.org/10.5465/amr.1998.192955

Brown, J. \& Duguid, P. (1998). Organizing knowledge. Californian Management Review, 40, (3), 90-111. https://doi.org/10.2307/41165945

Brown, J. \& Reingen, P. (1987). Social ties and word-of-mouth referral behavior. Journal of Consumer Research, 14(3), 350-362. https://doi.org/10.1086/209118

Bryant, S. (2005). The impact of peer mentoring on organizational knowledge creation and sharing: An empirical study in a software firm. Group \& Organization Management, 30(3), 319-338. https://doi.org/10.1177/1059601103258439

Byosiere, P. \& Luethge, D. (2008). Knowledge domains and knowledge conversion: An empirical investigation. Journal of Knowledge Management, 12(2), 67-78. https://doi.org/10.1108/13673270810859523

Carley, K. \& Krackhardt, D. (1990). Emergent asymmetiries in organizations. Paper presented at the Social Network Conference, San Diego, CA.

Chen, H., Jose Miguel, B., Ragsdell, G., \& An, X. (2019). Somatic and cultural knowledge: Drivers of a habitus-driven model of tacit knowledge acquisition. Journal of Documentation, 75(5), 927-953. https://doi.org/10.1108/JD-03-2018-0044 
Chung, C. \& Tsai, Q. (2009). The effects of regulatory focus and tie strength on word-of-mouth behaviour. Asia Pacific Journal of Marketing and Logistics, 21(3), 329-341. https://doi.org/10.1108/13555850910973829

Colurcio, M. \& Russo-Spena, T. (2013). Collaborative innovation: A focus on food SMES. In Muzzalupo, I. (Ed.) Food Industry: 647-668. London: InTech. https://doi.org/10.5772/54616

Connelly, C., Zweig, D., Webster, J., \& Trougakos, J. (2012). Knowledge hiding in organizations. Journal of Organizational Behavior, 33(1), 64-88. https://doi.org/10.1002/job.737

Davenport, T. \& Prusak, L. (1998). Working knowledge: How Organizations manage what they know. Boston, Massachusetts: Harvard Business School Press.

Davies, M. (1989). Connectionism, modularity, and tacit knowledge. British Journal for the Philosophy of Science, 40, 541-555. https://doi.org/10.1093/bjps/40.4.541

Desouza, K. (2003). Facilitating tacit knowledge exchange. Association for Computing Machinery, Communications of the ACM, 46(6), 85-88. https://doi.org/10.1145/777313.777317

Dou, W., Li, H., Zhou, N., \& Su, C. (2010). Exploring relationship satisfaction between global professional service firms and local clients in emerging markets. Journal of International Business Studies, 41(7), 1198-1217. https://doi.org/10.1057/jibs.2009.78

Droege, S. \& Hoobler, J. (2003). Employee turnover and tacit knowledge diffusion: A network perspective. Journal of Managerial Issues, 15(1), 50-64.

Frenzen, J. \& Nakamoto, K. (1993). Structure, cooperation, and the flow of market information. Journal of Consumer Research, 20(3), 360-375. https://doi.org/10.1086/209355

Gertler, M. (2003). Tacit knowledge and the economic geography of context, or the undefinable tacitness of being (there). Journal of Economic Geography, 3, 75-99. https://doi.org/10.1093/jeg/3.1.75

Ghoshal, S. \& Bartlett, C. (2000). Rebuilding behavioral context: A blueprint for corporate renewal. In Beer, M. and N. Nohria (Ed.), Breaking the Code of Change: 195-222. Boston, Massachusetts: Harvard Business School Press.

Gilson, L., \& Goldberg, C. (2015). Editors' comment: So, what is a conceptual paper? Group \& Organization Management, 40(2), 127-130. https://doi.org/10.1177/1059601115576425

Godes, D. \& Mayzlin, D., (2009). Firm-created word-of-mouth communication: Evidence from a field test. Marketing Science, 28(4), 721-739. https://doi.org/10.1287/mksc.1080.0444

Grant, R. (1997). The knowledge-based view of the firm: Implications for management practice. Long Range Planning, 30(3), 450-454. https://doi.org/10.1016/S0024-6301(97)00025-3 


\section{Macrothink}

Journal of Management Research

ISSN 1941-899X

2020, Vol. 12, No. 4

Grant, R. (1996a). Prospering in dynamically-competitive environments: Organizational capability as knowledge integration. Organization Science, 7, 375-387. https://doi.org/10.1287/orsc.7.4.375

Grant, R. (1996b). Toward a knowledge-based theory of the firm. Strategic Management Journal, 17, 109-122. https://doi.org/10.1002/smj.4250171110

Granovetter, M. (1983). The strength of weak ties: A network theory revisited. Sociological Theory, 1, 201-233. https://doi.org/10.2307/202051

Granovetter, M. (1973). The strength of weak ties. American Journal of Sociology, 78, 1360-1380. https://doi.org/10.1086/225469

Hadjimichael, D. \& Tsoukas, H. (2019). Toward a better under-standing of tacit knowledge in organizations: Taking stock and moving forward. Academy of Management Annals, 13(2), 672-703. https://doi.org/10.5465/annals.2017.0084

Haldin-Herrgard, T. (2000). Difficulties in diffusion of tacit knowledge in organizations. Journal of Intellectual Capital, 1(4), 357-365. https://doi.org/10.1108/14691930010359252

Hau, Y. S., Kim, B., \& Lee, H. (2016). What drives employees to share their tacit knowledge in practice? Knowledge Management Research \& Practice, 14(3), 295-308. https://doi.org/10.1057/kmrp.2014.32

Higgins, M. \& Kram, K. (2001). Reconceptualizing mentoring at work: A developmental network perspective. Academy of Management Review, 26(2), 264-288. https://doi.org/10.5465/amr.2001.4378023

Holste, J. \& Fields, D. (2005). The relationship of affect and cognition based trust with sharing and use of tacit knowledge. Academy of Management Proceedings, 2005(1), B1-B6. https://doi.org/10.5465/ambpp.2005.18779269

Hu, H., Wang, L., Jiang, L., \& Yang, W. (2019). Strong ties versus weak ties in word-of-mouth marketing. Business Research Quarterly, 22(4), 245-256. https://doi.org/10.1016/j.brq.2018.10.004

Huang, Q., Davison, R. M., \& Gu, J. (2011). The impact of trust, guanxi orientation and face on the intention of Chinese employees and managers to engage in peer-to-peer tacit and explicit knowledge sharing. Information Systems Journal, 21(6), 557-577. https://doi.org/10.1111/j.1365-2575.2010.00361.x

Huang, K., Wang, K. Y., \& Yao, Y. (2019). Social network and tacit knowledge acquisition: The role of entrepreneurs' social skill. International Journal of Organizational Innovation, $11(3), 315$.

Hurley, R. (2002). Putting people back into organizational learning. The Journal of Business \& Industrial Marketing, 17(4), 270-281. https://doi.org/10.1108/08858620210431679 
Johnsen, R. \& Ford, D. (2008). Exploring the concept of asymmetry: A typology for analyzing customer-supplier relationships. Industrial Marketing Management, 37(4), 471-483. https://doi.org/10.1016/j.indmarman.2007.05.004

Kogut, B. \& Zander, U. (1992). Knowledge of the firm, combinative capabilities, and the replication of technology. Organization Science, Focused Issue: Management of Technology, 3, 383-397. https://doi.org/10.1287/orsc.3.3.383

Lawler, E. (2004). Leading a virtuous-spiral organization. Leader to Leader, 32, 32-40. https://doi.org/10.1002/1tl.74

Li-Wei, W. \& Lin, J. (2013). Knowledge sharing and knowledge effectiveness: Learning orientation and co-production in the contingency model of tacit knowledge. The Journal of $\begin{array}{llll}\text { Business \& Industrial } \quad \text { Marketing, } & \text { 28(8), }\end{array}$ https://doi.org/10.1108/JBIM-04-2011-0050

Liao, C. (2005). A field study in the externalising of tacit knowledge in on-the-job training. International Journal of Management, 22, 79-88.

Linell, P. \& Luckmann, T. (1991) Asymmetries in dialogue: Some conceptual preliminaries. In Markova, I. and Foppa, K. (Ed.) Asymmetries in Dialogue: 1-20. Hemel Hempstead: Harvester Wheatsheaf.

Liu, T. (2005). Impacts on improvement of organizational synthetic value caused by social network relationship. Journal of American Academy of Business, 6(1), 102-109.

Liu, Y. \& Phillips, J. (2011). Examining the antecedents of knowledge sharing in facilitating team innovativeness from a multilevel perspective. International Journal of Information Management, 31(1), 44-52. https://doi.org/10.1016/j.ijinfomgt.2010.05.002

Lubit, R. (2001). The keys to sustainable competitive advantage: Tacit knowledge and knowledge management. Organizational Dynamics, 29(4), 164-178. https://doi.org/10.1016/S0090-2616(01)00026-2

Malhotra, Y. (2002). Why knowledge management systems fail? Enablers and constraints of knowledge management in human enterprises. In Holsapple, C.W. (Ed.), Handbook on Knowledge Management: 577-599. Heidelberg, Germany: Springer-Verlag. https://doi.org/10.1007/978-3-540-24746-3_30

Mead, S. (2001). Using social network analysis to visualize project teams. Project Management Journal, 32(4), 32-38. https://doi.org/10.1177/875697280103200405

Michalski, M., Montes, J. \& Narasimhan, R. (2019). Relational asymmetry, trust, and innovation in supply chain management: A non-linear approach. International Journal of Logistics Management, 30(1), 303-328. https://doi.org/10.1108/IJLM-01-2018-0011

Mitchell, J. (1969). The concept and use of social networks. In J.C. Mitchell (Ed.), Social Networks in urban situations: 1-50. Manchester, England: University of Manchester Press. 


\section{MlMacrothink}

Journal of Management Research

ISSN 1941-899X

2020, Vol. 12, No. 4

Nahapiet, J. \& Ghoshal, S. (1998). Social capital, intellectual capital, and the organizational advantage. Academy of Management Review, 23(2), 242-266. https://doi.org/10.5465/amr.1998.533225

Nonaka, I. (1994). A dynamic theory of organizational knowledge creation. Organization Science, 5, 14-37. https://doi.org/10.1287/orsc.5.1.14

Palacios-Marqués, D., Popa, S., \& Alguacil Mari, M. (2016). The effect of online social networks and competency-based management on innovation capability. Journal of Knowledge Management, 20(3), 499-511. https://doi.org/10.1108/JKM-05-2015-0175

Panahi, S., Watson, J. \& Partridge, H. (2013), Towards tacit knowledge sharing over social webtools. Journal of Knowledge Management, 17(3), 379-397. https://doi.org/10.1108/JKM-11-2012-0364

Polanyi, M. (1966). The Tacit Dimension. Gloucester, Massachusetts: Peter Smith.

Reed, R. \& Defillippi, R. (1990). Causal ambiguity, barriers to imitation, and sustainable competitive advantage. The Academy of Management Review, 15, 88-102. https://doi.org/10.5465/amr.1990.4308277

Reingen, P. \& Kernan, J. (1986). Analysis of referral networks in marketing: Methods and illustration. Journal of Marketing Research, 23(4), 370-378. https://doi.org/10.1177/002224378602300407

Rutten, W., Blaas-Franken, J., \& Martin, H. (2016). The impact of (low) trust on knowledge

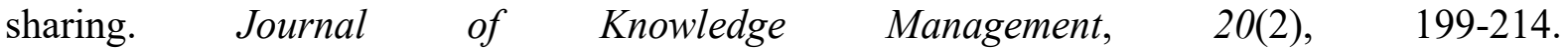
https://doi.org/10.1108/JKM-10-2015-0391

Seidler-de Alwis, R. \& Hartmann, E. (2008). The use of tacit knowledge within innovative companies: Knowledge management in innovative enterprises. Journal of Knowledge Management, 12(1), 133-147. https://doi.org/10.1108/13673270810852449

Selamat, M. \& Choudrie, J. (2004). The diffusion of tacit knowledge and its implications on information systems: The role of meta-abilities. Journal of Knowledge Management, 8, 128-139. https://doi.org/10.1108/13673270410529163

Simonin, B. (1999). Transfer of marketing know-how in international strategic alliances: An empirical investigation of the role and antecedents of knowledge ambiguity. Journal of International Business Studies, 30(3), 463-490. https://doi.org/10.1057/palgrave.jibs.8490079

Staber, U. \& Sydow, J. (2002). Organizational adaptive capacity: A structuration perspective. Journal of Management Inquiry, 11(4), 408-425. https://doi.org/10.1177/1056492602238848

Swap, W., Leonard, D., Shields, M. \& Abrams, L. (2001) Using mentoring and storytelling to transfer knowledge in the workplace. Journal of Management Information Systems, 18(1), 95-114. https://doi.org/10.1080/07421222.2001.11045668 
Thomas, R. \& Skinner, L. (2010). Total trust and trust asymmetry: Does trust need to be equally distributed in interfirm relationships? Journal of Relationship Marketing, 9(1), 43-53. https://doi.org/10.1080/15332660903551875

Wipawayangkool, K. \& Teng, J. (2016). Paths to tacit knowledge sharing: Knowledge internalization and individual-task-technology fit. Knowledge Management Research \& Practice, 14(3), 309-318. https://doi.org/10.1057/kmrp.2014.33

$\mathrm{Wu}, \mathrm{Z}$. (2011). A model of trust governance on partnership in knowledge supply chain. Contemporary Logistics, 4, 61-65. 